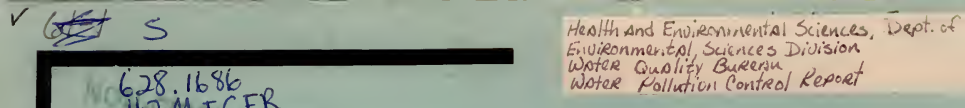

628 i I ICFR
it
961 C. 27

\title{
MACRO-INVERTEBRATES OF THE
}

CLARK FORK RIVER

MONTANA

STATE DOCUMENTS COLLECTION

$$
\text { AUS } 1 \cap 2005
$$

MONTANA STATE LIBRA I

1515 E. 6th AVE
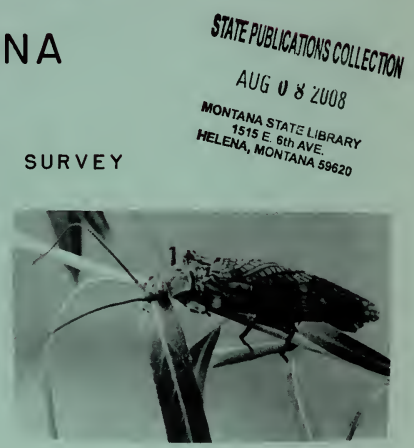

WATER POLLUTION CONTROL Report No. 6I-I

June-September

$1958-1959-1960$

Continuance from Biological Section
of Report No.59-1

MONTANA STATE BOARD OF HEALTH and

MONTANA STATE FISH AND GAME DEPT. 


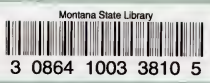


Prepared by:

ROBERT C. AVERETT

BIOLOGIST

POLLUTION CONTROL

MONTANA STATE FISH AND GAME DEPARTMENT
Survey Directed by:

C. W. BRINCK

DIRECTOR

ENVIRONMENTAL SANITATION DIVISION

MONTANA STATE EOARD OF HEALTH

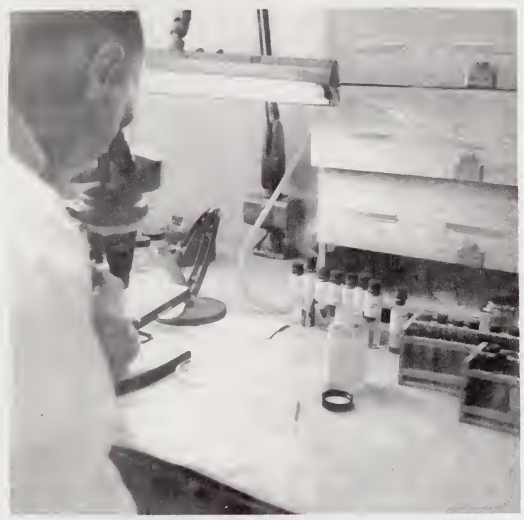

Identifying macro-invertebrates in laboratory

(Period of Field Studies - June - September 1958-1960 - Data and

Laboratory Analyses completed early 1961) 


\section{.}




\section{MONTANA STATE BOARD OF HEALTH}

David T. Berg, President (Helena)

R. J. Losleben, Vice-President (Malta)

H. W. Bateman, M.D. (Choteau)

Paul H. Bowden, D.D.S. (Butte)

Mrs. Elsie Hanson (Superior)

Mrs. Helen C. Johnson (Bozeman)

S. C. Pratt, M.D. (Miles City)
MONTANA WATER POLLUTION COUNCIL

Fred F. Palmer, Chairman (Forsyth)

Walter J. Everin, Vice-Chairman

(Helena)

Fred Buck, (Helena)

John B. Hazen (Butte)

Irving J. Staid (Billings)

G. D. Carlyle Thompson, M.D. (Helena) Winton Weydemeyer (Fortine)

\title{
PARTICIPATING GROUPS
}

\author{
Administered by \\ MONTANA STATE BOARD OF HEALTH \\ G. D. Carlyle Thompson, M. D. \\ Executive Officer \& Secretary \\ Environmental Sanitation Division \\ Claiborne W. Brinck, Director \& \\ Secretary, Montana Water Pollution Council
}

Water Pollution Control Staff

Donald G. Willems, Public Health Engineer

John C. Spindler, Aquatic Biologist (to July 1959)

Sheldon P. Hayes, Ph.D., Biologist, Chief, Summer Field Team

N. Bruce Hanes, Public Health Engineer, Summer Field Team (to Sept. 1959)

Martin Houle, Chemist, Summer Field Team (1958)

Hugh R. Mclean, Chemist, Summer Field Team (1959 \& 1960)

* Robert C. Averett, Biologist (1959 \& 1960)

* John M. Stubbs, Biological Assistant (1960)

\section{With Assistance From}

MONTANA FISH AND GAME DEPARTMENT

William Alvord, Chief of Fisheries

George D. Holton, Chief Fisheries Management Biologist

Arthur N. Whitney, District Fishery Manager

Ralph Boland, Fishery Biologist

Joe E. Huston, Fishery Biologist

Tommy L. Smith, Education Representative *Assigned to State Board of Health by Montana State Fish and Game
Department 
. 
"Macro-Invertebrates of the Clark Fork River in Montana" is the second report issued by the Montana State Board of Health of studies that have been made on the Clark Fork River. It is limited to the study of the biological aspects of the river from Warm Springs to St. Regis, and is in effect, a progress report designed to show the present biological condition of this portion of the Columbia River Drainage in Montana. It is based on work done during the months of June to September in each of the 1958, 1959 and 1960 years.

The report on "Macro-Invertebrates of the Clark Fork River in Montana" is a continuation of the first report, No. 59-1, which covered studies on the Clark Fork made between March and November 1957. It was entitled "An Extensive Chemical, Physical, Bacteriological Survey of the Columbia River Drainage in Montana". Both these studies have been made possible by augmenting the staff in the Stream Pollution Program in the Board's Division of Environmental Sanitation with the assignment of a fishery biologist by the Montana Fish and Game Commission.

The findings enumerated in the first study, together with other information gathered in 1958 was used as a basis for the classification of the waters of this Montana River Drainage. The official classification was made by the Water Pollution Council in December 1958 following public hearings which were held in the late summer of that year. The State Board of Health concurred with the Council's recommendations for this classification at its January 17, 1959 meeting.

Classification of Montana streams for their most beneficial use is a result of the passage of the revised Water Pollution Act by the Montana 1955 Legislature which created the Water Pollution Council. The State Board of Health, under policies established by the Council, is responsible for the administration of the Water Pollution Act, with the Board being authorized to modify Council actions when necessary to protect human health.

The improvement noted in this second report is the result of abatement measures recently effected. However, in the face of increased domestic, recreational and industrial uses, the task of keeping Montana's streams and lakes free from pollution reaches new proportions. To keep up with this task, continued survey studies are required in order to reveal both improvements and new sources of pollution.

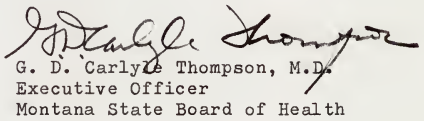



Introduction ........................ . I

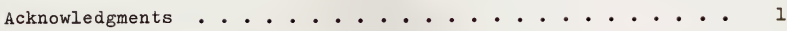

Location and Drainage . . . . . . . . . . . . . . I

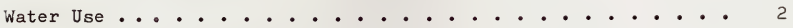

Classification of Water Use . . . . . . . . . . . 2

Recent Pollution ................. . . . 3

Stream Organisms and Pollution............. . . 4

Sampling Methods . . . . . . . . . . . . . 5

Stream Bottom Organisms of the Study Area . . . . . . . . 6

Findings and Discussion .............. . . . 7

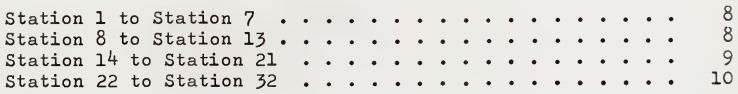

Summary . . . . . . . . . . . . . . . . 11

References Cited . . . . . . . . . . . . . . 11- 12

Tables: 1. Location and Descriptions of Sampling Stations . .13-14-15

2. Tabulation of Organisms Collected - 1958 . . . . 16

3. Tabulation of Organisms Collected - 1959 . . . . 17

4. Tabulation of Organisms Collected - 1960 ..... 18

5. Percent Composition of Organisms - 1958 . . . . 19

6. Percent Composition of Organisms - 1959 . . . . 20

7. Percent Composition of Organisms - 1960 . . . . 21

8. Stream Flow and pH Readings - 1958, 1959, 1960 . . 22

Figures 1. Map of Drainage Area... . . . . . . . . 23

2. Average Number of Bottom Organisms - 1958, 1959, 196024

3. Average Volume and Average Number of Bottom Organisms - 1960 . . . . . . . . . 25

4. Relative Location of Sampling Stations and percent Composition of Bottom Organisms - 1960.. . . . 26-27 



\section{INTRODUCTION}

This is the second report concerned with pollution investigations of the Clark Fork River. The first investigation was conducted during 1957, and was reported by Spindler (1959). It included the entire Columbia River drainage in Montana, of which the Clark Fork is a major stream, and contained chemical, physical, bacteriological and biological information.

This second investigation concerns that portion of the Clark Fork River mainstem from Warm Springs, Montana (mile 473, Station 1 - See Table 1) downstream to St. Regis, Montana (mile 266, Station 32). Except for $\mathrm{pH}$ readings taken at selected stations, this report is limited to a discussion of the aquatic biota, more specifically the aquatic macro-invertebrates, of the Clark Fork River. Data for this report were collected during 1958, 1959 and 1960.

\section{ACKNOWLEDGMENTS}

The studies reported here were conducted under the direction of the Office of Environmental Sanitation, Montana State Board of Health, and in conformance with the Water Pollution Act of 1955, as established by the $34 \mathrm{th}$ Legislative Assembly of Montana. Mr. C. W. Brinck, Director of the Division of Environmental Sanitation, administered the investigations, and reviewed the manuscript. Mr. Donald G. Willems, Sanitary Engineer, and Mr. John C. Spindler, Aquatic Biologist, located the original sampling stations, and developed the sampling techniques. Mr. George D. Holton, Chief Fishery Biologist with the Montana Fish and Game Department, reviewed the manuscript, and gave helpful suggestions.

The 1958 and 1959 sampling was carried out by the State Board of Health Summer Field Team. This team consisted of Dr. Sheldon P. Hayes, Microbiologist, Weber College, Utah; N. Bruce Hanes, Sanitary Engineer, Montana State College and H. R. McLean and Martin Houle, Chemists, formerly with the State Board of Health.

The 1960 survey was financed by the Montana State Fish and Game Department, in connection with a cooperative agreement with the State Board of Health. Mr. John M. Stubbs, formerly of Montana University and now with the Tennessee Game and Fish Commission, assisted the author with the 1960 sampling and tabulated some of the data. Mrs. Melva Rude, of the Montana State Board of Health, typed the manuscript.

\section{LOCATION AND DRAINAGE}

The Clark Fork River begins on the west side of the Continental Divide in Montana, near the City of Butte. It flows in a general northwest direction through western Montana and leaves the state to enter Idaho near the town of Heron, Montana. Figure 1 shows the main drainage systems of the Clark Fork River., Tributary streams of importance to this study are Warm Springs Creek, Little Blackfoot River, Flint Creek, Rock Creek, Big Blackfoot River, Rattlesnake Creek, Bitterroot River and the St. Regis River. 


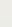


Although not under consideration in this report, the Flathead River drains a major portion of western Montana. This stream begins in British Columbia, Canada and flows in a general southward direction until it reaches the Clark Fork River.

For a more detailed description of the Clark. Fork drainage in Montana the reader is referred to spindler (1959), and to a $1959 \mathrm{re-}$ port by the U.S. Fish and Wildlife Service entitled Clark Fork River Basin Montana.

\section{WATER USE}

Water from the mainstem, within the study area, is used for irrigation, recreation (mainly fishing and waterfowl hunting), industry and waste disposal. Prior to 1960 a number of communities allowed untreated sewage to enter the river. Since 1960 the communities of Warm Springs, Deer Lodge and Drummond have installed sewage treatment facilities. Missoula, the largest city on the mainstem, has not, at the time of this writing, started construction of sewage treatment facilities. Its raw sewage is still being released into the Clark Fork River.

The Anaconda Company, with large mining and milling operations at Butte and Anaconda, uses the river above mile 473 (Station 1) for industrial waste disposal. This section of the river has been set aside for industrial waste disposal by the Water Pollution Act of 1955 (see next section). Prior to 1954, mine-mill waste was released directly into the river headwaters with a minimum of treatment. Beginning in 1954, the Anaconda Company constructed a series of waste treatment ponds above Station 1. In addition to these ponds, lime is added to the river near Warm Springs. The addition of lime raises the $\mathrm{pH}$ to the point where a coagulant is formed and solids are precipitated. As a result, a great improvement in water quality in the Clark Fork mainstem below Station 1 was noted after 1954. During 1957 game fish were taken as far upstream as Station 4 (Spindler, 1959).

\section{CLASSIFICATION OF WATER USE}

The Montana Water Pollution Council officially classified water use of the Clark Fork River in December 1958. Specifically, the Council recognizes five alphabetical codes for water use. They are: (A) water supply without treatment; (B) water supply with treatment; (C) recreation and swimming; (D) growth and propagation of fish and other aquatic life and; (E) agricultural and industrial use.

From mile 498 (extreme headwaters of Clark Fork mainstem) downstream to mile 472 (mouth of Warm Springs Creek) the Clark Fork mainstem is exempt from classification. From mile 472 downstream to mile 445 (mouth of the Little Blackfoot River) the mainstem is classified as "E". From mile 445 downstream to mile 418 (mouth of Flint Creek) the mainstem is classified as "E" until 1969. Thereafter it will be classified as "D" and "E". From mile 418 downstream to mile 365 (mouth of Big Blackfoot River) the mainstem is classified as "E" until 1964. From 1964 to 1969 it will be classified as "D" and "E" and thereafter will be classified as "B, C, D and E". From mile 365 downstream to mile 148 


$$
\text { . }
$$


(Montana-Idaho State Line) the mainstem is classified as "B, C, D and $E^{\prime \prime}$.

The time-limit classification from mile 472 downstream to mile 365 is designed to give the various upstream water users time to develop improved pollution abatement measures.

\section{RECENT POLLUTION}

During 1957, the Waldorf Paper Products Company, now known as the Waldorf-Hoerner Company established a pulp mill on the Clark Fork River near the Community of Frenchtown. Waste treatment facilities were incomplete when this mill began operations, and waste materials, beginning in early 1958, were released directly into the Clark Fork River. During July and early August of 1958, this waste material caused a fishkill below the mill effluent and altered the bottom organism composition in the mainstem. In addition, a profuse growth of filamentous bacteria (Spaerotilus) became established on the stream bottom (Whitney and spindler, 1959). Since August of 1958 the Waldorf-Hoerner Company has held their waste material in a series of lagoons, and, as will be shown later, the river has returned to its "normal" condition below the mill.

The lower one-half mile of Rattlesnake Creek, a small tributary stream to the Clark Fork River near Missoula, has been the victim of several fish-kills (Averett, 1960). Presumably these fish-kills were caused by the intermittent release of high-caustic waste water from the Missoula Brewing Company. Rattlesnake Creek is low in alkalinity and consequently does not have much buffer capacity for such wastes. Although this waste material undoubtedly reached the Clark Fork River, its effect upon the river has never been determined.

As mentioned under Water Use the Anaconda Company installed a complex series of settling ponds in the upper river beginning in 1954. These settling ponds plus the addition of lime to the river (to precipitate the suspended solids from solution) greatly improved the condition of the river from Station 1 (mile 473) downstream. During late 1959 and early 1960 a labor strike closed the mines, and mill and acid mine water again entered the Clark Fork River below mile 473 (station 1 ). Until mid-March of 1960, this red, high iron content, water was not evident below Milltown Dam (mile 365). Apparently the reservoir created by Milltown Dam was acting as a settling pond. However, after mid-March the red water began flowing over Milltown Dam, and the Clark Fork mainstem downstream from Milltown Dam, was discolored, in varying degrees, as far downstream as St. Regis, Montana (Station 32, mile 271). Fishkills of undetermined magnitude were evident in the Clark Fork River above Milltown Dam several times throughout the winter of 1960.

The Montana Power Company, the regulating agency of Milltown Reservoir, "flushed" Milltown reservoir during early July of 1960. Apparently the waste metals that had settled behind the dam were also released, because a fish-kill in the vicinity of the dam tailrace was noted.

The above pollution cases are mentioned so that the reader will have some insight into what has happened in the river since the 1957 survey.

One other type of pollution, namely siltation, should be mentioned here. Siltation in the Clark Fork River is common from mile 473 (Station 1) downstream to Missoula. Much of it is caused by irrigation return water, and overgrazing by livestock. Doubtless siltation has been going on for some time, and unless present land-use practices are changed, 

In summary then, pollution in the river since the 1957 survey has consisted of (1) pulp mill wastes near Frenchtown; (2) mine-mill wastes from Butte and Anaconda; (3) municipal wastes, primarily from Missoula and; (4) siltation.

\section{STREAM BOTTOM ORGANISMS AND POLLUTION}

The effects of pollution in a stream are fundamentally biological, and in many cases can be measured by the various responses exhibited by stream bottom organisms. Although, there are variations in the responses that stream bottom animals exhibit towards pollution, these responses usually follow a definite pattern.

Aquatic organisms are sometimes incorrectly used as pollution indicators. A common tendency is to give blanket labeling to some types of organisms as being tolerant to pollution, and to other types, as being intolerant. A host of complex events take place when a pollutant is placed in a stream. Some pollutants have a direct effect upon bottom organisms, while others have indirect effects (such as stream-bottom siltation) that may not take place until after a long period of time. Gaufin (1960) mentions some of the complexities involved in separating tolerant and intolerant species of aquatic organisms. He writes ". . some species may become more tolerant to certain pollutants by continuous exposure. In addition, closely related species of the same genus may display a vast difference in their tolerance levels."

\footnotetext{
There are basically three types of pollutants, organic, poisons and inorganic.
}

Organic pollution usually has the effect of lowering the dissolved oxygen content of the stream, and in many cases deposits a sludge bed on the stream bottom. Thus, the stream environment becomes suitable only for those organisms capable of obtaining oxygen from the atmosphere, or capable of existing on low amounts of dissolved oxygen. In addition, such stream animals may have to be capable of existing in or on a sludge bed. So-called clean water animals such as mayflies (Ephemeroptera), caddisflies (Trichoptera) and stoneflies (Plecoptera), generally require a relatively high dissolved oxygen content, and a clean, firm, stream bottom. When a stream section becomes organically polluted these clean water types are replaced by aquatic earthworms (Oligochaeta), some snails (Gastropoda) and some types of two-winged flies (Diptera).

In a clean water environment there is an association of many types of organisms, each type represented by relatively few individuals. In an organically polluted environment the number of types of organisms is reduced, but each type is represented by a great number of individuals. Thus, a definite change in the bottom organism population takes place when a stream receives organic pollution. This change is not always complete because clean water organisms are of ten found, in small numbers, in organically polluted stream sections. Hynes (1960) reports that riffle areas in a polluted stream zone may absorb enough dissolved oxygen to allow some clean water organisms to exist.

A poisonous substance, whether it be organic or inorganic in form, has a rather simple effect upon stream animals. Organisms can withstand so much poison and when more is administered they die and disappear. 

Inorganic pollution, such as siltation, and many industrial wastes, either acts as a poison, or alters the stream environment physically. Its end result is usually a drastic lowering of the stream animal population in the area affected.

Considering the three types of pollution discussed, i.e. organic, poisons and inorganic, we can expect at least three possible changes to take place in the stream animal population. They are (1) the population is altered in composition with some forms replacing others; (2) the population is partially destroyed and subsequently reduced in numbers or; (3) the entire population is destroyed.

After the removal of pollution the recovery rate of a population to its normal clean water status varies with each situation. Generally those streams that have numerous tributaries show the most rapid recovery. This is to be expected, as organisms living in the tributaries help to re-populate the previously polluted stream. The first organisms to reappear are usually those that have a short life cycle. Webb (1960) found that chironomids (larvae of a small two-winged fly) were the first to reappear in a stream polluted with DDT. He states, "After chironomids, signs of recovery were first evident in the case of small mayflies and stoneflies". He further mentions that the caddisflies showed particularly severe reductions after DDT pollution, and implies that their degree of recovery was slower than the mayflies and stoneflies. Webb did his work in Canada, and the same sequence of recovery may or may not take place in Montana. However, as will be shown later, a definite sequence of recovery has taken place in some sections of the Clark Fork River.

In summary, aquatic organisms can be used as indicators of pollution. Their use, however, must be correlated with a host of other factors. The mere assignment of one type as tolerant to pollution and another type as intolerant has little real meaning.

\section{SAMPLING METHODS}

A list of the sampling stations and their locations are found on Table 1. These are the same stations described by Spindler (1959). During the July 1960 sampling two modifications were made concerning the location of these sampling stations. Station 9 was changed from mile 420 to mile 427, because the author could not locate the access road to the station at mile 420 . This access road was later located, and the September 1960 samples were taken at mile 420 . Station 25 was permanently changed during July 1960 from mile 330 to mile 327 because of physical changes in the river channel. In addition to these changes, Rattlesnake Creek, Station 18, mile 358-1.0) was added to the July 1960 sampling list.

As Table 1 shows, samples were collected in seven tributary streams as well as in the Clark Fork mainstem. These tributary streams will be referred to as control streams throughout the remainder of this report.

The control streams were sampled to give some insight concerning their population composition, and to compare their aquatic organism populations with those found in the Clark Fork mainstem.

The control stream concept has been the center of much debate, and the author feels it deserves a short discussion here. There are at least three factors that must be taken into consideration concerning the 


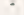


samples taken in the control streams. They are: (1) the population of aquatic organisms in the control stream may not be subject to the same fluctuations in numbers and volume as those in the mainstem; (2) chemical and physical characteristics of the control stream may be entirely different from those of the mainstem, and thus the population may be radically different and; (3) to assume that the population in the control stream is a "normal clean water" population, is also to assume that no pollution has entered the control stream. Because only one sampling station was established on each control stream, it is obviously impossible to have a good knowledge of their aquatic organism populations. Nevertheless, it is believed that samples collected in the control streams can be used as an index to "normal populations" even though the data must be used carefully.

All samples were collected in stream riffle areas. Experience has shown that the greatest diversity of stream bottom organisms is found in this type of habitat. Clean water organisms usually frequent the "fast water" areas of a stream, and any biological investigation concerned with the effects of pollution must be designed to sample these types.

Samples collected during the study were taken with a four-squarefoot sampler. This apparatus consists of a square metal frame measuring two feet on each side, and a three by four foot hand screen, constructed of standard window screen (approximately 14 meshes per inch), with two wooden handles. The four-square-foot frame is embedded in the stream bottom while the hand screen is held immediately downstream. The stream bottom within the four-square-foot frame is aggitated with the operators feet, or as during 1960, with a garden hoe. Bottom organisms within the area enclosed by the frame are thus dislodged and swept against the screen by the current. After collecting the sample in this manner, the screen is taken to the stream bank and laid over a white oilcloth. The organisms collected are "picked" from the screen, or in the case of those that fall through, from the oilcloth, and placed in a preservative. During 1958 and 1959, the samples were preserved in 5 percent formalin. The 1960 samples were preserved in 70 percent alcohol. tion.

A minimum of two four-square-foot samples were taken at each sta-

Samples collected in 1958 and 1959 were classified to order and enumerated in the field. No volumes were recorded for these samples. The 1960 samples were sorted and enumerated in the laboratory. Thus, it was possible to separate the Diptera (two-winged rilies) to the family level. Unfortunately, there was not enough available time to separate the other orders into family groups. Thus, a faster and much simpler grouping, as presented on Table 4, was used. Volumes were taken of the samples collected during 1960.

Not all the stations as listed on Table 1 were sampled during any one year of the study period. The most intense sampling was conducted during 1958 and 1960. Tables 2, 3, and 4 list the stations sampled, and the dates they were sampled for 1958, 1959 and 1960 respectively.

\section{STREAM BOTTOM ORGANISMS OF THE STUDY AREA}

Essentially the same types of organisms were found in the control streams as were found in the Clark Fork River. 

Immature insects of the Orders Diptera (two-winged flies), Trichoptera (caddisflies), Plecoptera (stoneflies), Ephemeroptera (mayflies), Coleoptera (beetles) and Odonata (dragonflies and damselflies) were found in the study area. Gastropoda (snails) and Oligochaeta (fresh-water earthworms) were also collected at several stations.

The Diptera collected during 1960 were found to represent five families. They were Simulidae (black flies), Tendipedidae (midges), Rhagionidae (snipe flies), Tipulidae (crane flies) and Tanyderidae (primative crane flies). The Tanyderidae are apparently rare in Montana and two specimens were sent to the Entomology Department of Montana State College. Lest the reader becomes confused, the Family Tendipedidae is known by some Zoologists as Family Chironomidae. For this report the name Tendipedidae will be used.

The Trichoptera were represented by members of the Family Brachycentridae; several forms that construct cases out of sand and some of the net-spinning forms (non-case makers). The author has experienced considerable difficulty in identifying the sand-case forms. Specimens of this type were sent to Montana State College, but at the time of this writing they have not been identified. Most of the net-spinning types appeared to be members of the Family Hydropsychidae.

The bulk of the Plecoptera were members of the Families Pteronarcidae or Perlidae. Several unidentified families were also present. The author examined a large number of Ephemeroptera nymphs under the microscope and found them all to be members of the Family Baetidae.

No attempt was made to separate the Coleoptera, Odonata, Gastropoda and Oligochaeta forms to the family level.

Stream velocities in cubic feet per second (cfs) and pH readings (except for 1959) were taken at selected stations. These data are presented on Table 8 . All pH readings were taken with a Hellige Color Comparator.

\section{FINDINGS AND DISCUSSION}

For the discussion the study area is divided into the following sub-sections: (1) Station 1 to Station ? (from Warm Springs to and including the Little Blackfoot River); (2) Station 8 to Station 13 (from the Little Blackfoot River to and including Rock Creek); (3) Station 14 to Station 21 (from Rock Creek to and including the Bitterroot River) and; (4) Station 22 to Station 32 (from the Bitterroot River to St. Regis, Montana (and including the St. Regis River).

Tables and Figures that supplement the discussion are found in the Appendix, and the reader is referred to them for specific sampling.results. The types of organisms collected during 1958, 1959; and 1960 are found in Tables 2,3 and 4 respectively. These tables also list the date the samples were collected, number of square feet of stream bottom sampled, total number of organisms collected for each station and, the average number of organisms collected per four-square-foot sample, at each station. Table 4, which concerns the 1960 samples, lists the total volume of organisms (in cubic centimeters) for each station, and the average volume per four-square-foot sample.

Figure 2 is a graphic presentation of these same data for 1958, 1959 , and 1960. 
. 
Figure 3, concerned only with the 1960 samples, is a graphic comparison between the average number of organisms and the average volume of organism per four-square-foot sample.

The percent composition of the various types of organisms collected in the samples are presented on Tables 5 (1958), 6 (1959) and 7 (1960). To supplement the 1960 data, the percent composition of the samples is illustrated in a series of pie graphs on Figure 4. The relative location of the sampling stations are also shown on Figure 4.

Because the 1960 samples are the most recent they are given special emphasis in the discussion that follows.

(1) Station 1 to Station 7: Mine-mill wastes prior to 1954, and the recent (1960) metal pollution have kept the aquatic organism population at a low level in this section.

Upon dislodging the stream bottom material a red precipitate (presumably iron) was noted during the July and September 1960 sampling periods. This precipitate has coated the underside of the stream bottom material in the Clark Fork mainstem and has undoubtedly eliminated this section as favorable habitat for many bottom-dwelling organisms. The July 1960 samples revealed that the highest percentage of organisms were Diptera larvae. By September, 1960 increased numbers of Trichoptera larvae were present. A comparison of average numbers to average volumes (Figure 3) reveals the small size of the organisms taken in this mainstem section.

Organism numbers were also low during 1958. Station 1, at the time of the 1958 sampling period, was a relatively new channel, and thus no organisms were taken in the samples.

warm Springs Creek (Station 2) had a relatively high organism population during both July and September 1960. However, the September samples contained twice the number of organisms for the same sampling effort, plus a significant amount of larger organisms.

The Little Blackfoot River population, (Station 7) remained almost the same in number for the same sampling effort, during both July and September 1960. An increase in volume was noted in September, and this was undoubtedly due to egg hatching and growth of the stream-bottom organisms between the July and september sampling periods.

This section of the mainstem study area is, then, in rather poor condition biologically. Although classified for industrial and agricultural use, the greatest strides in pollution abatement in the entire mainstem have been made in this area. The Anaconda Company has, with considerable expense, installed some rather efficient settling ponds to eliminate mine-mill waste from the stream. The communities of Warm Springs and Deer Lodge, which were once a source of major pollution in the area, have recently constructed sewage treatment facilities. With the continuation of such efforts, this section of the stream may someday be biologically productive.

(2) Station 8 to Station 13: This section comprises that portion of the study area from below the mouth of the Little Blackfoot River to Rock Creek.

Samples collected during July 1958 contained relatively high numbers of organisms at each station within this section. 

Only Station 8 was sampled in this section during 1959. It contained a high number of organisms, primarily Diptera. The July 1960 samples taken at the mainstem stations showed a low number of organisms per four-square-foot sample, and a correspondingly low volume. This low volume was again due to the presence of small Diptera in the samples.

The mainstem stations, in this section, showed increased numbers of Trichoptera larvae during the september 1960 sampling period with the exception of Station 12 which contained primarily Diptera larvae.

Station 9 contained 90 percent Trichoptera, primarily Hydrosphidae. This population "boom" of Trichoptera larvae in the mainstem was probably a re-establishment of this organism following the mine-mill pollution of late 1959 and early 1960. A fish-kill was reported in this area during February 1960, and if the metal pollution was severe enough to kill fish, it was undoubtedly severe enough to kill many of the gill-breathing bottom organisms.

Two control streams are located in this mainstem section. They are Flint Creek (Station 10) and Rock Creek (Station 13). These two streams showed great variability in numbers and volume, and illustrate the differences one can expect to find in streams flowing through unlike watersheds. The Flint Creek samples for July 1960 contained only 12 percent Diptera, whereas the September samples contained 83 percent Diptera. The Diptera collected during September were primarily members of the Family Simulidae. A comparison of numbers to volume in Figure 3 shows that the volume or size of individual insects was larger in July than in september. Again this was due to the abundance to small Diptera. The 1958 samples collected in Flint Creek contained much higher numbers and higher percentages of Trichoptera than did the 1960 samples. This population change cannot be explained with the information available. It could be due to seasonal variations existing between 1958 and 1960, or due to undetected pollution in lower Flint Creek.

Rock Creek, station 13, is well known for its large Plecoptera nymphs, primarily members of the Pteronarchidae and Perlidae families. As a result volumes were higher in relation to numbers in this stream station during both July and September 1960. Hynes (1960) reports that most Plecoptera spend the warm summer months either in the adult or eg8 form. This is perhaps true of warm valley-floor streams, but does not hold true for Rock Creek. The 1960 samples for Rock Creek contained 76 and 60 percent Plecoptera nymphs for July and September respectively. During 1958 the July samples collected at Rock Creek contained 34 percent Plecoptera and 48 percent Ephemeroptera. This again was probably a normal seasonal variation.

In summary, the mainstem section from the Little Blackfoot River to Rock Creek revealed rather low numbers of organisms during July of 1960. By September, a population "boom" appeared to be in progress, and the more sensitive gill-breathing organisms were returning to the mainstem sections.

(3) Station 14 to Station 21: This section of the study area extends from below Rock Creek to the Bitterroot River.

Pollution in this section has consisted of mine-mill waste (March and July 1960) and domestic sewage from the city of Missoula.

Stations 14 and 15 are above Milltown Dam. Relatively high numbers of Diptera were taken at these stations during each sampling year 

(Station 14 was not sampled during 1959). However, before 1960, these stations contained a rather high population of Plecoptera nymphs. The July 1960 samples revealed a noticeable reduction in these nymphs, with a marked increase by September 1960. The mine-mill pollution of early 1960 undoubtedly lowered the Plecoptera population at these two stations. By September 1960 it appeared that re-establishment of Plecoptera nymphs was taking place, presumably from Rock Creek.

Station 17, located below Milltown Dam, contained primarily Diptera larvae during July 1960. By September 1960 a significant increase in Trichoptera was noted. Trichoptera were abundant at this station during both July and September of 1958, indicating that Trichoptera normally find suitable habitat in this area. This population "boom" of Trichoptera during September of 1960 was undoubtedly due to re-invasion of this organism following the mine-mill pollution earlier in the year including the flushing of Milltown Reservoir.

Mainstem Stations 19 and 20 are referred to as the Missoula sewage stations. This is particularly true of Station 19. Relatively large populations of oligochaeta have been recorded at these stations. However, even Oligochaeta numbers were low (absent at Station 20) during July of 1960. There is reason to believe that the mine-mill pollution of March 1960 had an effect upon the mainstem as far downstream as Station 23. Six trout were held in live-cars at Station 23 during this period. Some of the trout showed distress after 67 hours and four of the six died within 90 hours. Trout held in a control live car in Rattlesnake Creek showed normal activity throughout the 90-hour period.

Three control streams are located within this section of the study area. The Big Blackfoot River, Station 16, contains a population of bottom organisms that is well balanced, but low in numbers. Rattlesnake Creek, Station 18, was sampled only during July of 1960. At this time the majority of the organisms taken were Ephemeroptera. Samples collected further upstream on Rattlesnake Creek, in connection with another study, also revealed high numbers of Ephemeroptera nymphs. Ephemeroptera nymphs predominated during the 1959 and 1960 sampling periods at Station 21 in the Bitterroot River. The 1958 samples collected at this station contained higher percentages of both Diptera and Plecoptera than Ephemeroptera. The aquatic organism population in the Bitterroot River at Station 21 does, however, appear to be well balanced.

This sub-section of the Clark Fork River (Stations 14 to 2l) shows the effects of past pollution, with the subsequent re-establishment of some types of organisms. Unfortunately, no samples were collected in the section during september of 1960.

(4) Station 22 to Station 32: Sub-section 4 extends from below the mouth of the Bitterroot River to below the mouth of the St. Regis River. Past pollution in this area of the mainstem has centered around stations 23, 24 and 25, and consisted of pulp mill waste material. This pollution by pulp mill waste began in early 1958 and ceased by mid-August of the same year. During late July of 1958 it caused a severe fish-kill in the Clark Fork mainstem. Low dissolved oxygen values were not evident in the river at this time, as the lowest oxygen value recorded was 5.0 parts per million. It is suspected that the fish-kill resulted from either acute or chronic toxicity of the pulp mill waste material. Since the pulp mill began impounding its waste during midAugust of 1958 there has been a steady improvement in the bottom-organism population at Stations 23, 24 and 25. This improvement is evident by the samples collected at these stations during July of 1960. 

Mainstem Stations 26, 27,28,29, 30 and 32 show high populations of Trichoptera larvae. This section of the Clark Fork is undoubtedly effected by the Missoula sewage during low summer flows, but in general, shows a high percentage of pollution-sensitive organisms.

The St. Regis River, the only control streams in this section, contained a balanced population of aquatic organisms. Here again, the Trichoptera were the most numerous.

\section{SUMMARY}

The upper Clark Fork River from Station 1 to Station 7 is in rather poor condition biologically. Mine-mill wastes, and previous domestic waste, have lowered the biological productivity of this river section. Although this portion of the river is classified for industrial and agricultural use, recent pollution abatement measures will undoubtedly increase its biological productivity.

From the mouth of the Little Blackfoot River downstream to Station 17 (below Milltown Dam) the mainstem showed improvement during the September 1960 sampling period. Doubtless these changes in population composition were due to seasonal variation as well as improved water quality. Nevertheless, the presence of relatively large numbers of gillbreathing organisms indicates that they can exist in this section of the river.

During low water periods the mainstem of the Clark Fork River below Station 17, is still effected by the Missoula sewage. The effects of this sewage are primarily noticeable at stations 19 and 20 , where large populations of oligochaeta are found during low river flows.

Below the mouth of the Bitterroot River to Station 32, the mainstem appears to be in good biological condition. Large populations of gill-breathers, primarily Trichoptera, constitute the aquatic organism population. That area of the river mainstem affected by pulp mill waste, Stations 24 and 25, now appears to have fully recovered.

Pollution abatement on the Clark Fork has progressed at a rapid rate. Future years should see the end of all serious pollution, and the return of the river to a clean water condition.

\section{REFERENCES CITED}

Averett, Robert C. 1960. Summary of recent fish-kills occurring in Montana. Montana Fish and Game Dept., May: 6 pp. Multilith Report.

Gaufin, A. R. 1960. Biological indicators of organic enrichment in fresh water. Biological Problems in Water Pollution. U. S. Dept. of Health, Education and Welfare, Transactions of the 1959 Seminar: p. 237.

Hynes, H. B. No 1960. The biology of polluted waters. University Press of Liverpool, Liverpool, England: 202 p.

Spindler, John C. 1959. An extensive chemical, physical, bacteriological and biological survey. Columbia River drainage in Montana. Montana State Board of Health, Progress Report No. 59-1: 111 p. 
Webb, F. E. 1960. Aerial forest spraying in Canada in relation to effects on aquatic life. U. S. Dept. of Health, Education and Welfare, transactions of the 1959 Seminar: pp 66-76.

Whitney, Arthur N. and John C. Spindler, 1959. Effects of kraft paper wastes on a Montana stream. Trans. Am. Fish. Coc., Vol. 88 (2): p. 153 . 

TABLE 1. Location and descriptions of sampling stations. Cłark Fork River and control streams.

STATION

NUMBER

1

2

3 Clark Fork River below Warm Springs.

4 Clark Fork River above Deer Lodge.

5 Clark Fork below Deer Lodge.

6

7

8

Clark Fork River above Drummond and Hint Creek.

Clark Fork River above Little

Blackfoot River and Garrison.

Little Blackfoot River above the Clark Fork River.

Clark Fork River below Little Blackfoot River and Garrison.

10 Flint Creek above the Clark Fork River.
MILEAGE

INDEX

\section{$\underline{\text { DESCRIPTION }}$}

473

$472-0.5$

469

456

452

447

$445-1.0$

443

427

420

$418-2.0$
1000 yards southeast of Mont. Fish \& Game Department game bird farm.

One-quarter mile downstream from Warm Springs State Hospital.

Two miles north of Warm Spgs. along U.S. Highway 10, thence one mile east and 150 feet upstream from bridge crossing.

About one mile south of Deer Lodge at bridge crossing Clark Fork on $10 \mathrm{~S}$.

About four miles north of Deer Lodge on $10 \mathrm{~s}$.

Two miles southeast of U.S. Highways 1OS-10W junction on $10 \mathrm{~S}$.

One and four tenths miles northeast of $10 \mathrm{~S}-10 \mathrm{~N}$ junction on Tom Sherlock ranch of $f$ lOS.

One and one-half miles west of Garrison on U.S. Highway 10 about 100 yards downstream from the Silver Star Bar.

July 1960 - Immediately below the Wallace Bridge.

September 1960 - One and nine tenths miles west of Drummond on 10 to third access road (on south side of highway) from city limits sign.

Two and six-tenths miles south of Drummond along U.S. $10 \mathrm{~A}$, thence east seventenths mile to large red barn along New Chicago road, thence north four-tenths mile to a point about 100 yards downstream from the confluence of Lower Willow Creek with Flint Creek. 

Page 2. (Table 1)

STATION

NUMBER

11

12 Clark Fork River above Rock Creek.

13 Rock Creek above the Clark Fork River.

14 Clark Fork River below Rock Creek.
MILEAGE

INDEX

414

386

$382-2.0$

381

369

(Big) Blackfoot River.

16 Blackfoot River above the Clark Fork.

Clark Fork River below the Blackfoot River.

(East Missoula Station).

18 Rattlesnake Creek above the Clark Fork.

19 Clark Fork River below

Missoula and above the Bitterroot River.

(Missoula Sewage Station)

20 Clark Fork River above the Bitterroot River.

21 Bitterroot River above the Clark Fork River.
$365-2.0$

363

$358-1.0$

354

352

$351-1.0$

349

\section{DESCRIPTION}

Three and three-tenths miles west of Drummond on U.S. 10 .

About 300 yards south of railway station at Bonita.

Two miles south of U.S. 10 on Rock Creek road at first point at which creek can be seen from road.

Two and three-tenths miles west on U.S. 10 from Rock Creek road. One and onetenth miles downstream from confluence of Rock Creek with the Clark Fork and about 200 yards upstream from Albert Rude ranch.

Two and four-tenths miles east of junction of Montana Highway 20 and U.S. 10 on the Petersen ranch.

One and six-tenths miles northeast of 20-10 junction and upstream from Bonner.

Three and three-tenths miles west of Milltown along U.S. 10 and across road from R. L. Deschamps Ranch.

One mile above mouth in Greenough Park.

About one-half mile downstream from the Daly Meat Company slaughterhouse on the old Mullan Road.

At the west end of Third Avenue on the O.G. Onlear residence.

Above U.S. 93 and railway bridges about one mile south of District No. 2 Fish \& Game Headquarters south of Missoula.

On the H. Jay Cusker ranch off the old Mullan Road, south and west of Missoula. 
STATION

NUMBER

23

Clark Fork River at Deep

Creek. (Deep Creek Station)

24 Clark Fork River at the Marcure Ranch.

(Marcure Ranch Station)

25 Clark Fork River at Six Mile. (Six-Mile Station)

Clark Fork at Nine-Mile.

Clark Fork River below Alberton

(Sawmill Gulch Station).

27 Clark Fork River at Forest

Grove.

(Quartz Ranger Station)

28 Clark Fork River above Trout Creek and Superior. Superior.
29 Clark Fork River below

MILEAGE

INDEX

342

338

330

327

313

295

292

282

30

Clark Fork River above St. Regis.

272

$271-2.0$

St. Rerk.

32

Clark Fork River below St. Regis.

266

\section{DESCRIPTION}

South and west of Missoula on the old Mullan Road. Turn south at the Primrose Railway Station at W.J. Sullivan mail box. One-quarter mile upstream from bridge crossing river at Deep Creek.

On the Marcure Ranch about two river miles downstream from proposed Waldorf Paper Company pulp mill site.

(1958-1959) About one and one-half miles south of the Six-Mile Bar and Cafe on U.S. 10. (1960) Immediately behind the Mel Armstrong Ranch.

Four and six-tenths miles west of Alberton on U.S. 10 .

Eighteen and six-tenths miles west of Alberton on U.S. 10 and 200 yards upstream from the Forest Grove Campgrounds.

Three-quarter mile downstream from Lozeau on U.S. 10.

Two miles downstream from Superior and one and ninetenths miles along the old St.Regis road and about onehalf mile downstream from the Mitchell (or Oakley) ranch. A Conoco Service Station can be seen on U.S.10 opposite this station.

About seven-tenths mile upstream from the Railway bridgeU.S. 10 overpass east of St. Regis.

At the Little Joe Creek Road Crossing.

Three.miles downstream from St. Regis on the St.RegisParadise Ferry road and east of Butler Gulch. 
$\bullet$ 


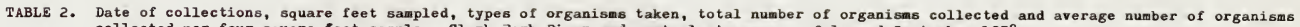
collected per four-square-foot sample. Clark Pork River and control streams - - July and September 1958.

Average

No. Per

Station Number

\begin{tabular}{|c|c|}
\hline 1 & $7-8$ \\
\hline 2 & $7-9$ \\
\hline 3 & $7-9$ \\
\hline 5 & $\begin{array}{l}7-9 \\
7-9\end{array}$ \\
\hline 6 & $7-10$ \\
\hline$?$ & $7-10$ \\
\hline 8 & $7-10$ \\
\hline 9 & $7-10$ \\
\hline 10 & $7-10$ \\
\hline 11 & $7-11$ \\
\hline 12 & $7-11$ \\
\hline 13 & $7-11$ \\
\hline 14 & $7-11$ \\
\hline 15 & $7-14$ \\
\hline 16 & $\begin{array}{l}9-2 \\
7-14\end{array}$ \\
\hline & $9-2$ \\
\hline 17 & $7-14$ \\
\hline 18 & $9-2$ \\
\hline 19 & $7-16$ \\
\hline 20 & $\begin{array}{l}9-5 \\
7-17\end{array}$ \\
\hline 21 & $7-14$ \\
\hline 22 & $\begin{array}{l}9-2 \\
7-15\end{array}$ \\
\hline C2 & $9-4$ \\
\hline 23 & $\begin{array}{l}7-15 \\
9-4\end{array}$ \\
\hline 24 & $7-15$ \\
\hline 25 & $7-16$ \\
\hline 26 & $\begin{array}{l}9-4 \\
7-16\end{array}$ \\
\hline & $9-16$ \\
\hline 27 & ?-17? \\
\hline 28 & $\begin{array}{l}7-17 \\
9-5\end{array}$ \\
\hline 29 & $7-17$ \\
\hline 30 & $\begin{array}{l}9-5 \\
7-18\end{array}$ \\
\hline 31 & $\begin{array}{l}9-5 \\
7-18\end{array}$ \\
\hline 32 & $7-18$ \\
\hline
\end{tabular}

Sq. Ft. Sampled

0

\begin{tabular}{l}
8 \\
8 \\
8 \\
8 \\
8 \\
8 \\
8 \\
8 \\
8 \\
8 \\
8 \\
8 \\
8 \\
8 \\
8 \\
8 \\
8 \\
8 \\
8 \\
8 \\
\hline
\end{tabular}

$$
\text { Not }
$$

8
8
8
8
8
8
8
8
8
8
8
8
8
8
8
8
8
8
8
8
8
8
8

26
280

21
39

39
181

29
522

522
38

162
41

103
248
20

20
8

8
10

10
10

13
42

42
18
28

28
56
32

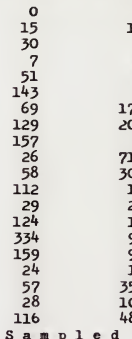

Trichoptera

Plecoptera

Gastropoda

Oligochaeta

0
0
0
0
0
5
29
35
1
4
36
0
118
160
27
268
10
57
41
262

a m P 1 ed

0
16
2
4
0
2
178
202
6
710
309
18
21
18
98
96
15
356
107
484
$d$
25
50
6
17
52
26
1106
9
385
6
48
410
103
653
1269
124
581
347
803
317
542
139
1602

0
0
12
0
0
0
0
0
0
0
0
0
0
0
1
7
0
0
0
0

0
3
0
0
3
0
0
0
0
0
0
5
1
7
0
0
0
0
0
0

Coleoptera

Ephemeroptera

0
2
1
3
8
6
6
17
4
1
3
11
9
3
12
12
4
27
0
8

0
2
2
0
15
6
67
19
10
42
8
14
164
24
20
17
57
35
19
16

27
23
3

3
15
184

184
31

113
7

122

4
14
27
15
10
7
6
5
3
23
8
8
27
48

1230
30
11
0
5
1
0
0
0
111
14
0
0
0
0
42
22
0
5
16
22
0
0




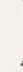




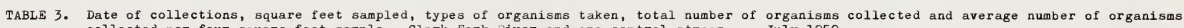
collected per four-square-foot sample. Clark Fork River and one control stream - - July 1959.

Average

No. Per

Station

Number

Sq. Ft.

Date Sampled

Trichoptera

plecoptera Gastropoda

oligochaeta

Coleoptera

Ephemeroptera

Other No. Ft.Sample

$6 \quad 7-1$

80

6
80
62
6
10
17
8
8
5
13
12
169
60

2
6
42
2
10
15
7
8
1
21
5
10
16

0
0
0
2
2
6
163
0
5
0
2
2
2

1
8
18
0
8
0
3
6
4
0
10
10
2

1
18
276
19
110
37
82
44
47
54
38
403
25

$$
7-16
$$$$
7-16
$$$$
\text { 7-17 }
$$

$7-18$

7-18

0
0
0
1
0
1
1
0
0
0
0
0
0

50
0
0
0
0
0
1
0
0
0
1
0
0

140

70

$567 \quad 284$

$\begin{array}{rr}972 & 486 \\ 58 & 29\end{array}$

$199 \quad 100$ 


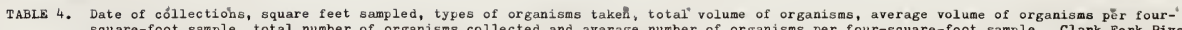
square-foot sample, total number of organisms collected and average number of organisms per four-square-foot sample. Clark Fork River and control streams - - July and September 1960.

Av.Vol. Av.No.

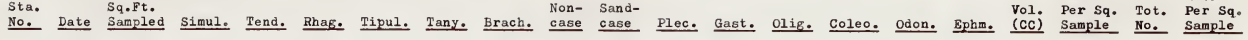

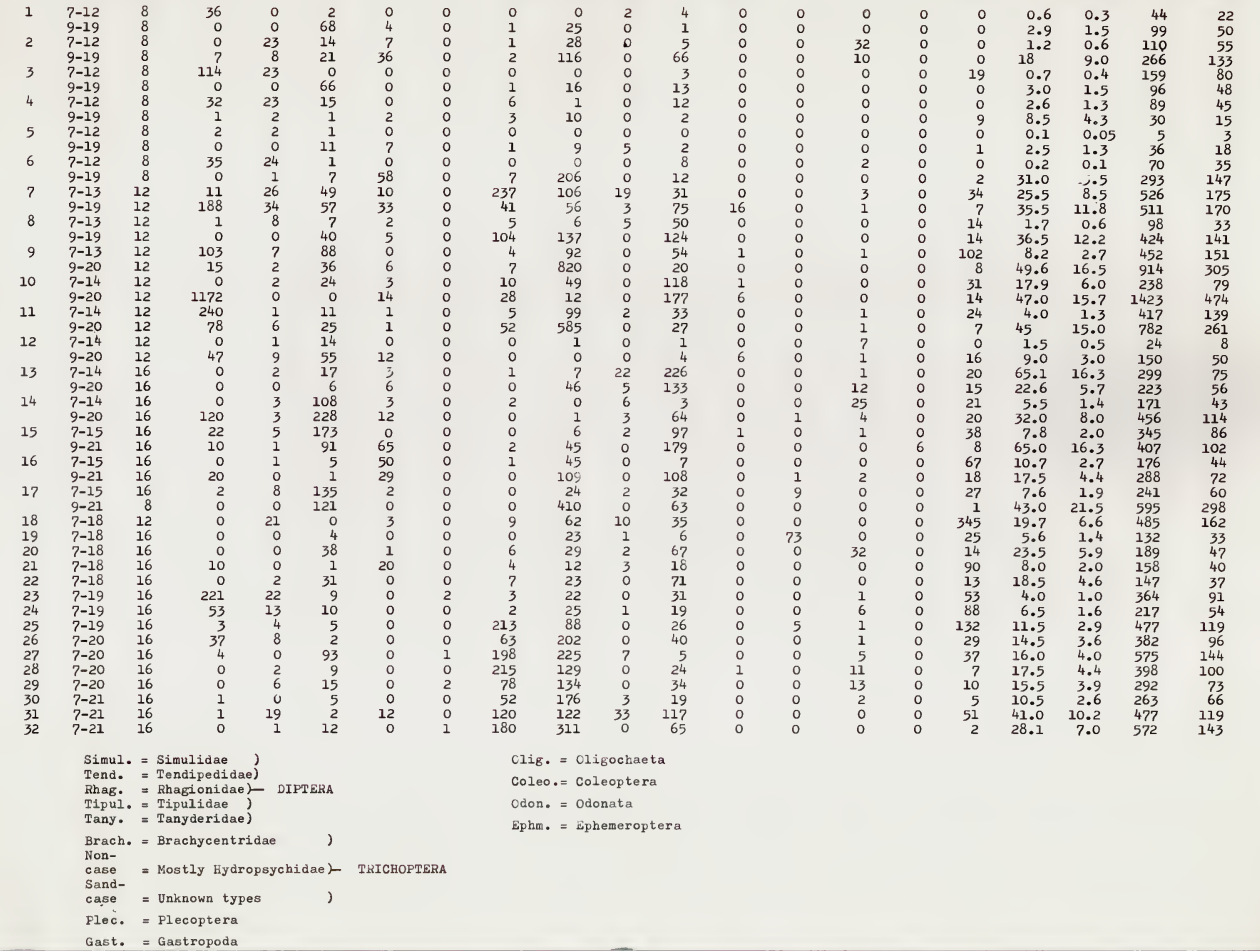


TABLE 5. Percent composition of bottom organisms collected in the Clark Fork River and control streams - - July and September 1958.

(Note: All percentages given are in whole numbers and are accurate within \pm 1 percent. A dash $(-)$ indicates that organisms were present in the sample, but were not abundant enough to be listed as a whole number. A zero $(0)$ indicates that the particular organism was not present in the sample. See Figure 2 for complete list of organisms collected. Gastropoda and Oligochaeta are listed under 'Other'.)

\begin{tabular}{|c|c|c|c|c|c|c|c|c|}
\hline $\begin{array}{l}\text { Station } \\
\text { Number }\end{array}$ & Date & $\begin{array}{c}\text { Total } \\
\text { No. } \\
\end{array}$ & Diptera & Trichoptera & Plecoptera & Coleoptera & Ephemeroptera & Other \\
\hline 1 & $7-8$ & 0 & 0 & 0 & 0 & 0 & 0 & 0 \\
\hline 2 & $7-9$ & 38 & 40 & 42 & 0 & 5 & 5 & 8 \\
\hline 3 & $7-9$ & 48 & 63 & 4 & 0 & 2 & 4 & 27 \\
\hline 4 & $7-9$ & 14 & 50 & 29 & 0 & 21 & 0 & $\begin{array}{r}21 \\
0\end{array}$ \\
\hline 5 & $7-9$ & 77 & 66 & 0 & 0 & 10 & 20 & 4 \\
\hline 6 & $7-10$ & 162 & 88 & 1 & 3 & 4 & 4 & 0 \\
\hline$?$ & $7-10$ & 349 & 20 & 51 & 8 & 2 & 19 & 0 \\
\hline 8 & $7-10$ & 408 & 32 & 49 & 9 & 4 & 5 & 1 \\
\hline 9 & $7-10$ & 178 & 88 & 4 & - & 2 & 6 & 0 \\
\hline 10 & $7-10$ & 783 & 3 & 91 & 1 & - & 5 & 0 \\
\hline 11 & $7-11$ & 414 & 14 & 75 & 9 & - & 2 & 0 \\
\hline 12 & $7-11$ & 162 & 69 & 11 & 0 & 7 & 9 & 4 \\
\hline 13 & $7-11$ & 343 & 9 & 6 & 34 & 3 & 48 & - \\
\hline 14 & $7-11$ & 336 & 37 & 5 & 48 & 1 & 7 & 2 \\
\hline 15 & $7-11$ & 495 & 68 & 20 & 6 & 2 & 4 & - \\
\hline & $9-2$ & 561 & 28 & 17 & 48 & 2 & 3 & 2 \\
\hline 16 & $7-14$ & 110 & 22 & 13 & 9 & 4 & 52 & 0 \\
\hline & $9-2$ & 532 & 11 & 67 & 11 & 5 & 6 & 0 \\
\hline 17 & $7-14$ & 195 & 14 & 55 & 21 & 0 & 10 & 0 \\
\hline & $9-2$ & 886 & 13 & 55 & 30 & - & 2 & 0 \\
\hline 18 & $\mathrm{~N}$ & $0 \mathrm{t}$ & $\mathrm{S}$ a m p 1 e & $d$ & & & & \\
\hline 19 & $7-16$ & 1323 & 2 & 2 & 2 & - & 1 & 93 \\
\hline & $9-5$ & 393 & 71 & 13 & 6 & - & 2 & 8 \\
\hline 20 & $7-17$ & 61 & 34 & 10 & 5 & 30 & 3 & 18 \\
\hline 21 & $7-14$ & 92 & 42 & 19 & 16 & 7 & 15 & 1 \\
\hline & $9-2$ & 649 & 28 & 8 & 28 & 8 & 27 & 1 \\
\hline 22 & $7-15$ & 106 & 27 & 25 & 29 & 5 & 11 & 3 \\
\hline & $9-4$ & 2020 & 26 & 55 & 6 & 2 & 11 & - \\
\hline 23 & $7-15$ & 75 & 51 & 12 & 9 & 9 & 19 & 0 \\
\hline & $9-4$ & 739 & 22 & 52 & 16 & 2 & 8 & 0 \\
\hline 24 & $7-15$ & 162 & 25 & 4 & 3 & 0 & 0 & 68 \\
\hline 25 & $7-16$ & 198 & 52 & 24 & 7 & 0 & 20 & 7 \\
\hline & $9-4$ & 750 & 33 & 55 & 4 & - & 8 & - \\
\hline 26 & $7-16$ & 145 & 14 & 71 & 10 & 2 & 2 & 1 \\
\hline & $9-4$ & 777 & 12 & 84 & 1 & - & 3 & 0 \\
\hline 27 & $7-17$ & 1284 & $\bar{z}$ & 100 & - & - & 0 & 0 \\
\hline 28 & $7-17$ & 185 & 6 & 67 & 3 & 1 & 0 & 23 \\
\hline & $9-5$ & 626 & 2 & 93 & 1 & - & 0 & 4 \\
\hline 29 & $7-17$ & 373 & 4 & 93 & 1 & 1 & 1 & 0 \\
\hline & $9-5$ & 891 & 5 & 90 & 3 & 1 & - & 1 \\
\hline 30 & $7-18$ & 372 & 5 & 85 & 2 & 1 & 1 & 6 \\
\hline & $9-5$ & 602 & 5 & 90 & 1 & - & 0 & 4 \\
\hline 31 & $7-18$ & 357 & 15 & 39 & 8 & 2 & 36 & 0 \\
\hline 32 & $7-18$ & 1689 & 2 & 95 & 3 & - & - & 0 \\
\hline
\end{tabular}


TABLE 6. Percent composition of bottom organisms collected in the clark Fork kiver and one control stream - - July 1959.

(Note: All percentages given are in whole numbers and are accurate within \pm 1 percent. A dash (-) indicates that organisms were present in the sampie, but were not abundant enough to be listed as a whole number. A zero (0) indicates that the particular organism was not present in the sample. See Table 3 for complete list of organisms collected. Gastropoda and Oligochaeta are listed under 'Other'.)

\begin{tabular}{|c|c|c|c|c|c|c|c|c|}
\hline $\begin{array}{l}\text { Station } \\
\text { Number } \\
\end{array}$ & Date & $\begin{array}{l}\text { Total } \\
\text { No. } \\
\end{array}$ & Diptera & Trichoptera & Plecoptera & Coleoptera & Ephemeroptera & Other \\
\hline 6 & $7-13$ & 140 & 57 & 4 & 1 & 1 & 1 & 36 \\
\hline 8 & $7-14$ & 567 & 80 & 14 & 1 & 2 & 3 & 0 \\
\hline 15 & $7-16$ & 972 & 59 & 7 & 4 & 2 & 28 & 0 \\
\hline 16 & $7-14$ & 58 & 48 & 10 & 4 & 0 & 33 & 5 \\
\hline 17 & $7-16$ & 199 & 30 & 5 & 5 & 4 & 55 & 1 \\
\hline 19 & $7-17$ & 576 & 87 & 3 & 3 & 0 & 6 & 1 \\
\hline 20 & $7-17$ & 331 & 20 & 2 & 2 & 1 & 25 & 50 \\
\hline 21 & $7-17$ & 87 & 24 & 9 & 9 & 7 & 51 & 0 \\
\hline 22 & $7-18$ & 70 & 12 & $?$ & 1 & 6 & 67 & 7 \\
\hline 23 & $7-18$ & 155 & 43 & 8 & 14 & 0 & 35 & 0 \\
\hline 24 & $7-16$ & 92 & 26 & 13 & 6 & 11 & 41 & 3 \\
\hline 25 & $7-18$ & 781 & 24 & 22 & 1 & 1 & 52 & - \\
\hline 26 & $7-18$ & 143 & 27 & 42 & 11 & 1 & 18 & 1 \\
\hline
\end{tabular}


TABLE 7. Percent composition of bottom organisms collected in the Clark Fork River and control streams - - July and September 1960.

(Note: All percentages given are in whole numbers and are accurate within \pm 1 percent. A dash (-) Indicates that organisms were present in the sample, but were not abundant enough to be listed as a whole number. A zero (0) indicates that the particular organism was not present in the sample. See Table 4 for complete list of organisms collected. Gastropoda and Oligochaeta are listed under 'Other',)

\begin{tabular}{|c|c|c|c|c|c|c|c|c|}
\hline $\begin{array}{l}\text { Sta. } \\
\text { No. } \\
\end{array}$ & $\underline{\text { Date }}$ & $\begin{array}{c}\text { Total } \\
\text { No. } \\
\end{array}$ & Diptera & Trichoptera & Plecoptera & Coleoptera & Ephemeroptera & Other \\
\hline \multirow[t]{2}{*}{1} & $7-12$ & 44 & 86 & 5 & 9 & 0 & 0 & 0 \\
\hline & $9-19$ & 99 & 73 & 26 & 1 & 0 & 0 & 0 \\
\hline \multirow[t]{2}{*}{2} & $7-12$ & 110 & 40 & 26 & 5 & 29 & 0 & 0 \\
\hline & $9-19$ & 266 & 27 & 44 & 25 & 4 & 0 & 0 \\
\hline \multirow[t]{2}{*}{3} & $7-12$ & 159 & 86 & 0 & 2 & 0 & 12 & 0 \\
\hline & $9-19$ & 96 & 69 & 18 & 13 & 0 & 0 & 0 \\
\hline \multirow[t]{2}{*}{4} & $7-12$ & 89 & 79 & 8 & 13 & 0 & 0 & 0 \\
\hline & $9-19$ & 30 & 20 & 43 & 7 & 0 & 30 & 0 \\
\hline \multirow[t]{2}{*}{5} & $7-12$ & 5 & 100 & 0 & 0 & 0 & 0 & 0 \\
\hline & $9-19$ & 36 & 50 & 42 & 5 & 0 & 3 & 0 \\
\hline \multirow[t]{2}{*}{6} & $7-12$ & 70 & 86 & 0 & 11 & 3 & 0 & 0 \\
\hline & $9-19$ & 293 & 22 & 74 & 4 & 0 & - & 0 \\
\hline \multirow[t]{2}{*}{7} & $7-13$ & 526 & 20 & 68 & 5 & 1 & 6 & 0 \\
\hline & $9-19$ & 511 & 61 & 20 & 15 & - & 1 & 3 \\
\hline \multirow[t]{2}{*}{8} & $7-13$ & 98 & 19 & 16 & 51 & 0 & 14 & 0 \\
\hline & $9-19$ & 424 & 11 & 57 & 29 & 0 & 3 & 0 \\
\hline \multirow[t]{2}{*}{9} & $7-13$ & 452 & 44 & 21 & 12 & - & 23 & - \\
\hline & $9-20$ & 914 & 7 & 90 & 2 & 0 & 1 & 0 \\
\hline \multirow[t]{2}{*}{10} & $7-14$ & 238 & 12 & 25 & 50 & 0 & 13 & - \\
\hline & $9-20$ & 1432 & 83 & 3 & 13 & 0 & 1 & $\overline{-}$ \\
\hline \multirow[t]{2}{*}{11} & $7-14$ & 417 & 61 & 25 & 8 & - & 6 & 0 \\
\hline & $9-20$ & 782 & 14 & 81 & 4 & - & 1 & 0 \\
\hline \multirow[t]{2}{*}{12} & $7-14$ & 24 & 63 & 4 & 4 & 29 & 0 & 0 \\
\hline & $9-20$ & 150 & 82 & 0 & 3 & - & 11 & 4 \\
\hline \multirow[t]{2}{*}{13} & $7-14$ & 299 & 7 & 10 & 76 & $=$ & 7 & 0 \\
\hline & $9-20$ & 223 & 5 & 23 & 60 & 5 & $?$ & 0 \\
\hline \multirow[t]{2}{*}{14} & $7-14$ & 171 & 66 & 5 & 2 & 15 & 12 & 0 \\
\hline & $9-20$ & 456 & 80 & 1 & 14 & 1 & 4 & - \\
\hline \multirow[t]{2}{*}{15} & $7-15$ & 345 & 58 & 2 & 29 & - & 11 & - \\
\hline & $9-21$ & 407 & 41 & 12 & 44 & - & 2 & 1 \\
\hline \multirow[t]{2}{*}{16} & $7-15$ & 176 & 32 & 26 & 4 & 0 & 38 & 0 \\
\hline & $9-21$ & 288 & 17 & 38 & 38 & 1 & 6 & - \\
\hline \multirow[t]{2}{*}{17} & $7-15$ & 241 & 61 & 11 & 13 & 0 & 11 & 4 \\
\hline & $9-21$ & 595 & 20 & 69 & 11 & 0 & - & 0 \\
\hline 18 & $7-18$ & 485 & 5 & 17 & 7 & 0 & 71 & 0 \\
\hline 19 & $7-18$ & 132 & 3 & 18 & 5 & 0 & 19 & 55 \\
\hline 20 & $7-18$ & 189 & 21 & 20 & 35 & 17 & 7 & 0 \\
\hline 21 & $7-18$ & 158 & 20 & 12 & 11 & 0 & 57 & 0 \\
\hline 22 & $7-18$ & $14 ?$ & 22 & 21 & 48 & 0 & 9 & 0 \\
\hline 23 & $7-19$ & 364 & 70 & $?$ & 8 & - & 15 & 0 \\
\hline 24 & $7-19$ & 217 & 35 & 13 & 9 & 3 & 40 & 0 \\
\hline 25 & $7-19$ & $47 ?$ & 3 & 63 & 5 & - & 28 & 1 \\
\hline 26 & $7-20$ & 382 & 12 & 69 & 11 & - & 8 & 0 \\
\hline 27 & $7-20$ & 575 & 17 & 75 & 1 & 1 & 6 & 0 \\
\hline 28 & $7-20$ & 398 & 3 & 86 & 6 & 3 & 2 & 0 \\
\hline 29 & $7-20$ & 292 & 8 & 73 & 12 & 4 & 3 & - \\
\hline 30 & $7-21$ & 263 & 2 & 89 & $?$ & - & 2 & 0 \\
\hline 31 & $7-21$ & 477 & $?$ & 58 & 25 & 0 & 10 & 0 \\
\hline 32 & $7-21$ & 572 & 2 & 86 & 11 & 0 & 1 & 0 \\
\hline
\end{tabular}


TABLE 8 Stream flow (in cubic feet per second) and pH data for Clark Fork River and control streams - - 1958, 1959 and 1960.

(Note: A dash (-) indicates that readings were not taken. Flow data collected with a velocity head rod and U. S. Geological Survey current meter. All flows listed below Station 16 (except Station 18) supplied by U. S. Geological Survey.)

1958

\begin{tabular}{|c|c|c|c|c|c|c|}
\hline \multicolumn{4}{|c|}{1958} & \multicolumn{3}{|c|}{1959} \\
\hline Station & Date & Flow & $\mathrm{pH}$ & Station & Date & Flow \\
\hline 1 & $7-8$ & - & 7.1 & 6 & $7-13$ & 230 \\
\hline 2 & $7-9$ & - & 7.9 & 8 & $7-14$ & 321 \\
\hline 4 & $7-9$ & - & 7.7 & 15 & $7-16$ & 1120 \\
\hline 6 & $7-10$ & - & 7.8 & 16 & $7-14$ & 2470 \\
\hline 7 & $7-10$ & - & 7.8 & 17 & $7-16$ & 3590 \\
\hline 9 & $7-10$ & - & 8.2 & 19 & $7-17$ & 3590 \\
\hline 10 & $7-10$ & - & 8.1 & 20 & $7-17$ & 3590 \\
\hline 12 & $7-11$ & - & 8.0 & 21 & $7-17$ & 2330 \\
\hline 13 & $7-11$ & - & 7.5 & 22 & $7-18$ & 5740 \\
\hline 15 & $7-11$ & - & 8.1 & 23 & $7-18$ & 5740 \\
\hline & $9-2$ & - & 8.4 & 24 & $7-16$ & 6110 \\
\hline 16 & $7-14$ & 1521 & $\begin{array}{l}8.4 \\
8.4\end{array}$ & $\begin{array}{l}25 \\
26\end{array}$ & $7-18$ & - \\
\hline 17 & $\begin{array}{l}9-2 \\
7-14\end{array}$ & $\begin{array}{r}630 \\
3382\end{array}$ & $\begin{array}{l}8.4 \\
8.1\end{array}$ & & $7-18$ & - \\
\hline & $9-2$ & 1356 & 8.4 & & & \\
\hline 20 & $7-17$ & - & 8.2 & & & \\
\hline 21 & $\begin{array}{l}7-14 \\
9-2\end{array}$ & - & $\begin{array}{l}8.5 \\
8.2\end{array}$ & & & \\
\hline 23 & $7-15$ & 4952 & 7.9 & & & \\
\hline 25 & $\begin{array}{l}9-4 \\
7-16\end{array}$ & $\begin{array}{c}1922 \\
-\end{array}$ & $\begin{array}{l}7.9 \\
8.1\end{array}$ & & & \\
\hline & $9-4$ & - & 8.2 & & & \\
\hline 28 & $7-17$ & - & 8.1 & & & \\
\hline & $9-8$ & - & 8.2 & & & \\
\hline 30 & $7-18$ & - & 8.1 & & & \\
\hline 31 & $\begin{array}{l}9-5 \\
7-18\end{array}$ & - & $\begin{array}{l}8.4 \\
8.0\end{array}$ & & & \\
\hline 32 & $7-18$ & $\overline{-}$ & 8.0 & & & \\
\hline
\end{tabular}

\begin{tabular}{|c|c|c|c|c|}
\hline Station & Date & Time & Flow & $\mathrm{pH}$ \\
\hline \multirow[t]{2}{*}{1} & $7-12$ & 1300 & 97 & 8.2 \\
\hline & $9-19$ & 0900 & 98 & 7. \\
\hline \multirow[t]{2}{*}{2} & $7-12$ & 1335 & 14 & 0 \\
\hline & $9-19$ & 0945 & 5 & \\
\hline \multirow[t]{2}{*}{4} & $7-12$ & 1515 & 51 & 8.0 \\
\hline & $9-19$ & 1115 & - & 10 \\
\hline \multirow[t]{2}{*}{6} & $7-12$ & 1710 & 118 & \\
\hline & $9-19$ & 1300 & 235 & 8. \\
\hline \multirow[t]{2}{*}{7} & $7-13$ & 1000 & 60 & 8.0 \\
\hline & $9-19$ & 1345 & 40 & . \\
\hline \multirow[t]{2}{*}{9} & $7-13$ & 1410 & 173 & 7.8 \\
\hline & $9-20$ & 0945 & 240 & 8. \\
\hline \multirow[t]{2}{*}{10} & $7-14$ & 0945 & 25 & 7.8 \\
\hline & $9-20$ & 1045 & 66 & \\
\hline \multirow[t]{2}{*}{12} & $7-14$ & 1315 & 500 & 8.2 \\
\hline & $9-20$ & 1330 & - & 8.2 \\
\hline \multirow[t]{2}{*}{13} & $7-14$ & 1430 & 450 & .2 \\
\hline & $9-20$ & 3425 & - & .2 \\
\hline \multirow[t]{2}{*}{15} & $7-15$ & 0910 & - & .0 \\
\hline & $9-21$ & 0845 & - & \\
\hline \multirow[t]{2}{*}{16} & $7-15$ & 1015 & - & 8.2 \\
\hline & $9-21$ & 0945 & - & 8.2 \\
\hline \multirow[t]{2}{*}{17} & $7-15$ & 1115 & 2,000 & 8.2 \\
\hline & $9-21$ & 1030 & 1,300 & 8.0 \\
\hline 18 & $7-10$ & 0935 & 22 & 7.2 \\
\hline 20 & $7-18$ & 1250 & - & 8.2 \\
\hline 21 & $7-18$ & 1400 & - & 7.6 \\
\hline 23 & $7-19$ & 0915 & - & 7.8 \\
\hline 25 & $7-19$ & 1500 & - & 8.0 \\
\hline 28 & $7-20$ & 1015 & - & 8.0 \\
\hline 30 & $7-21$ & 0945 & - & 8.0 \\
\hline 31 & $7-21$ & 1110 & - & 7.6 \\
\hline 32 & $7-21$ & 1300 & 4,020 & 8.0 \\
\hline
\end{tabular}




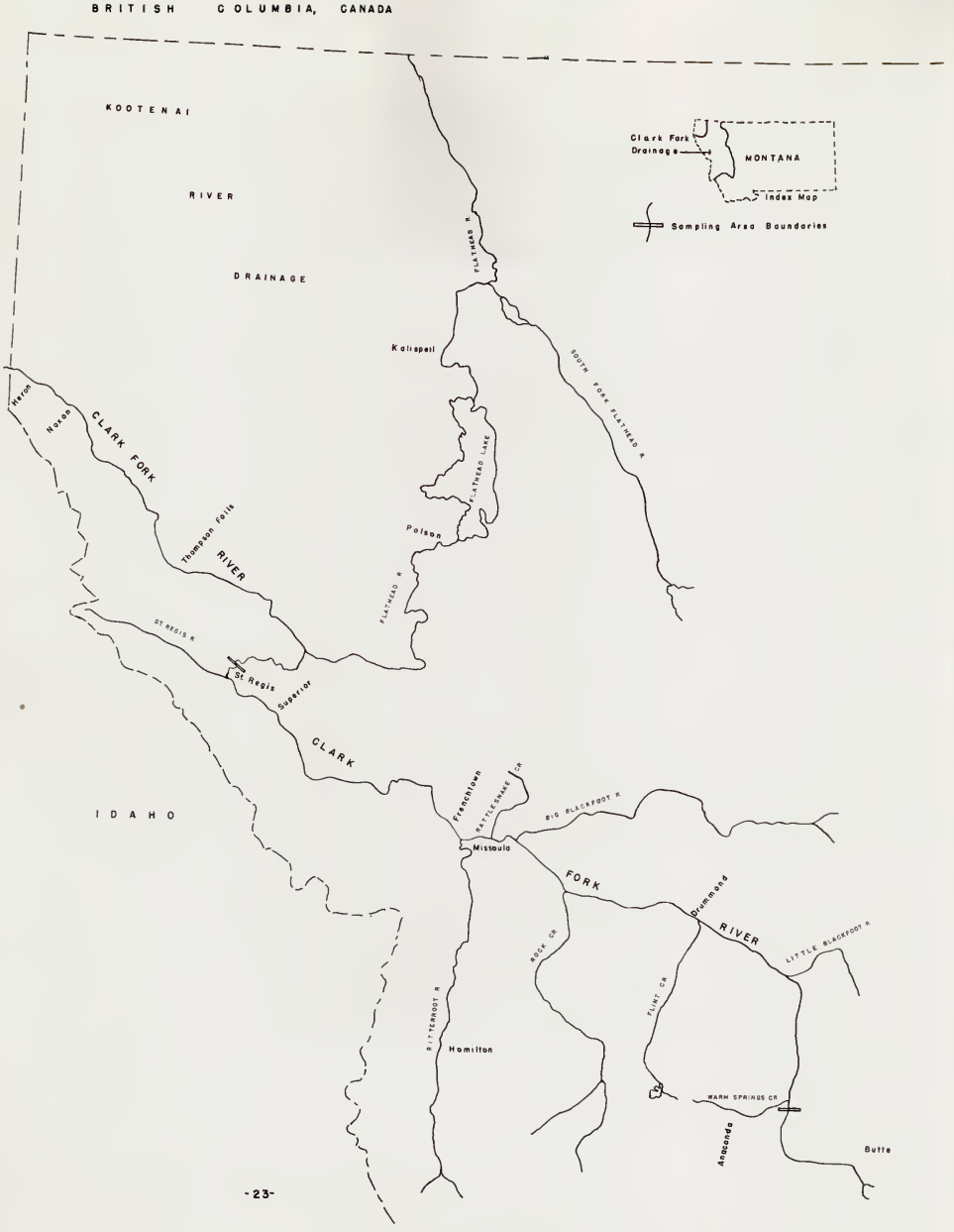


4 


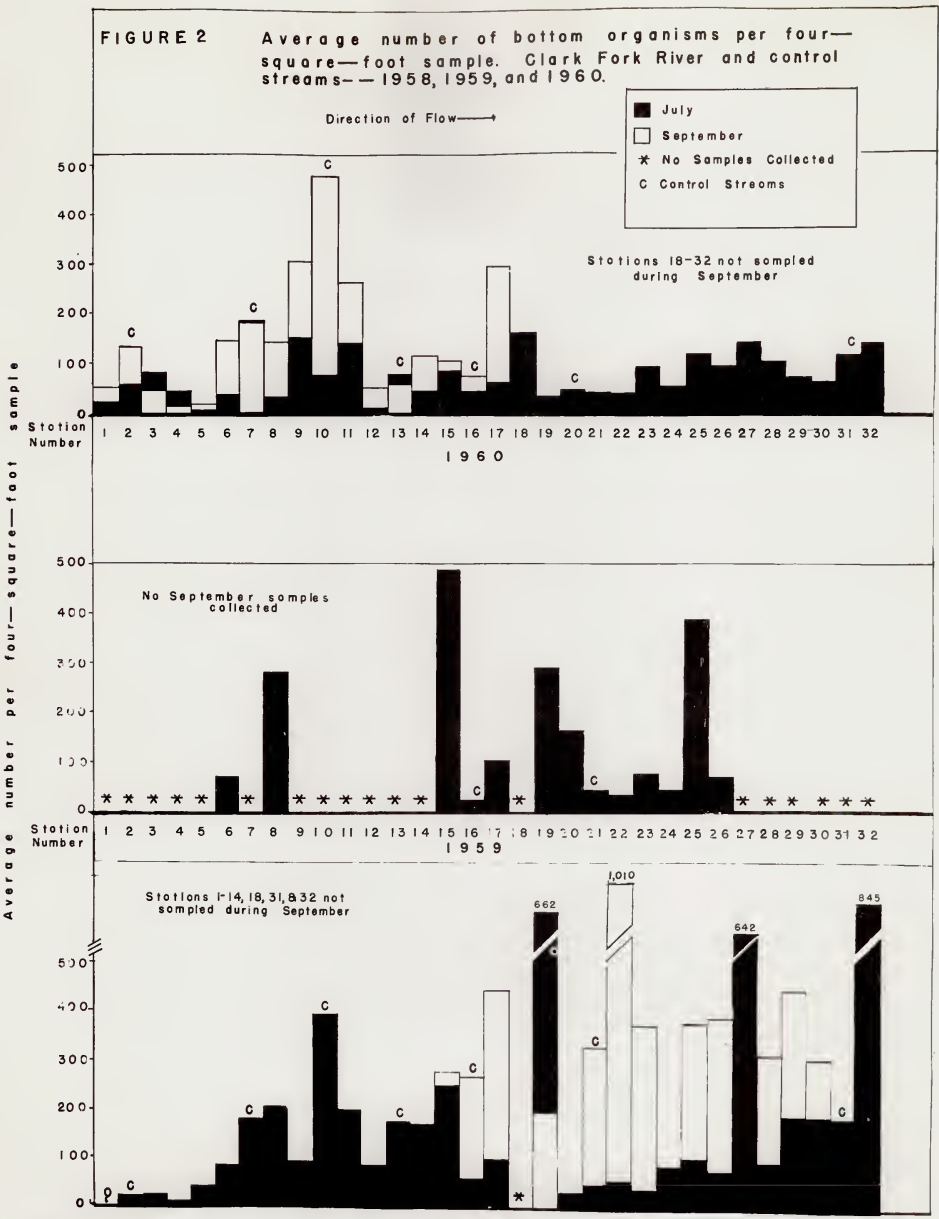

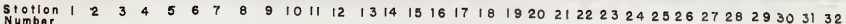
1958 


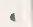

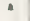


FIGURE 3 Average volume ond average number of bottom orgonisms per four-squore-faot somple. Clork Fork River ond control streoms--1960.

DULY

口 SEPremaer

* control streams

all values stapt at 'ó base line

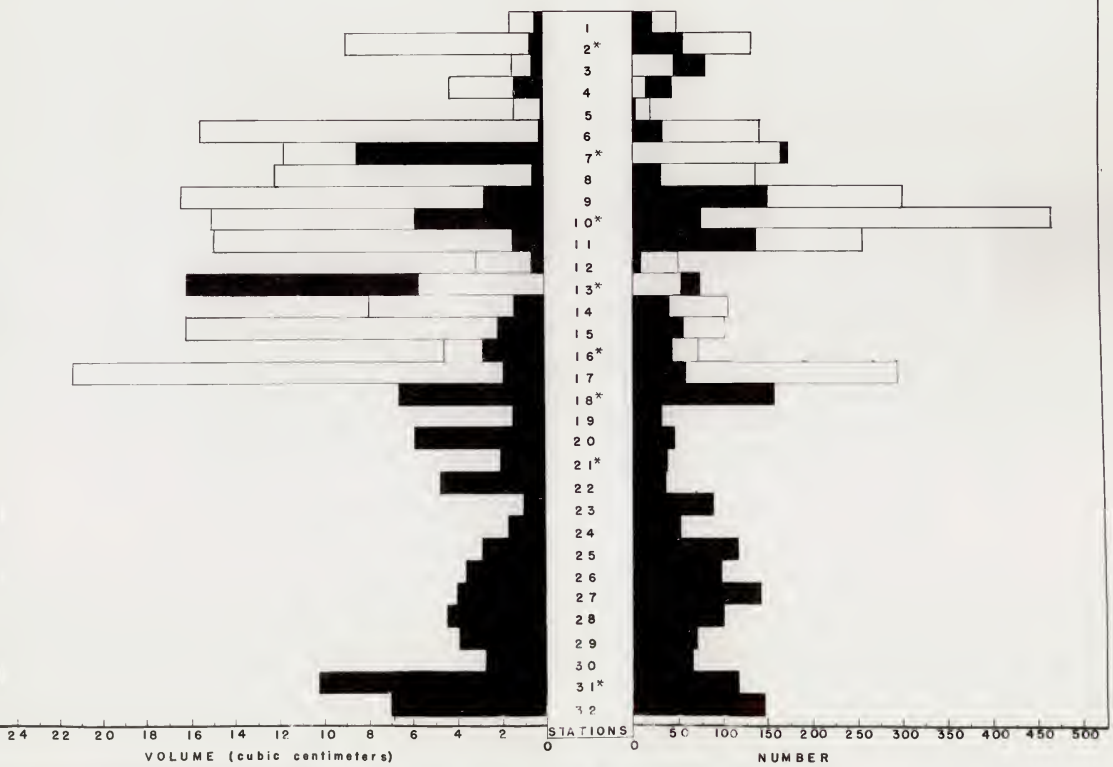


$+$ 


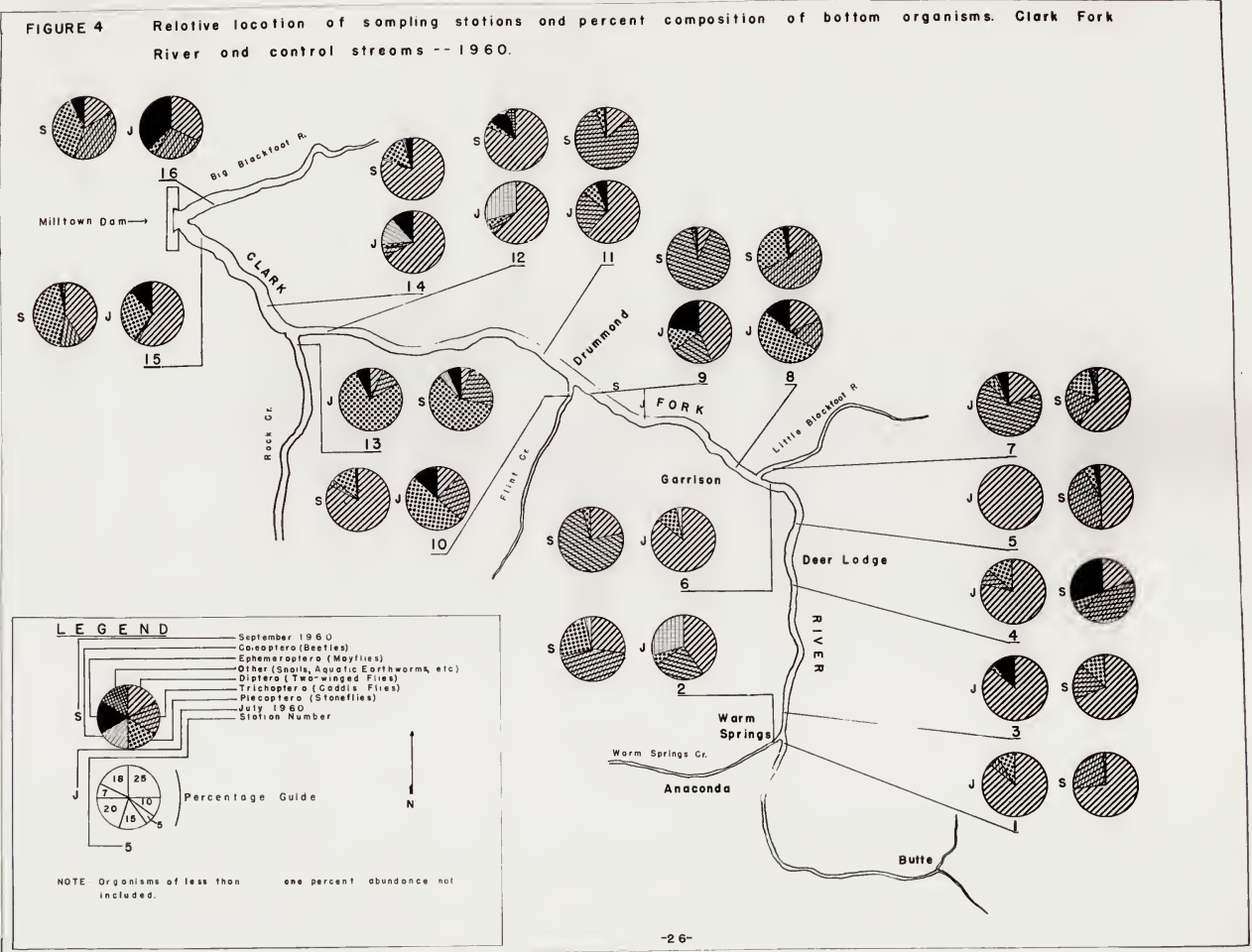




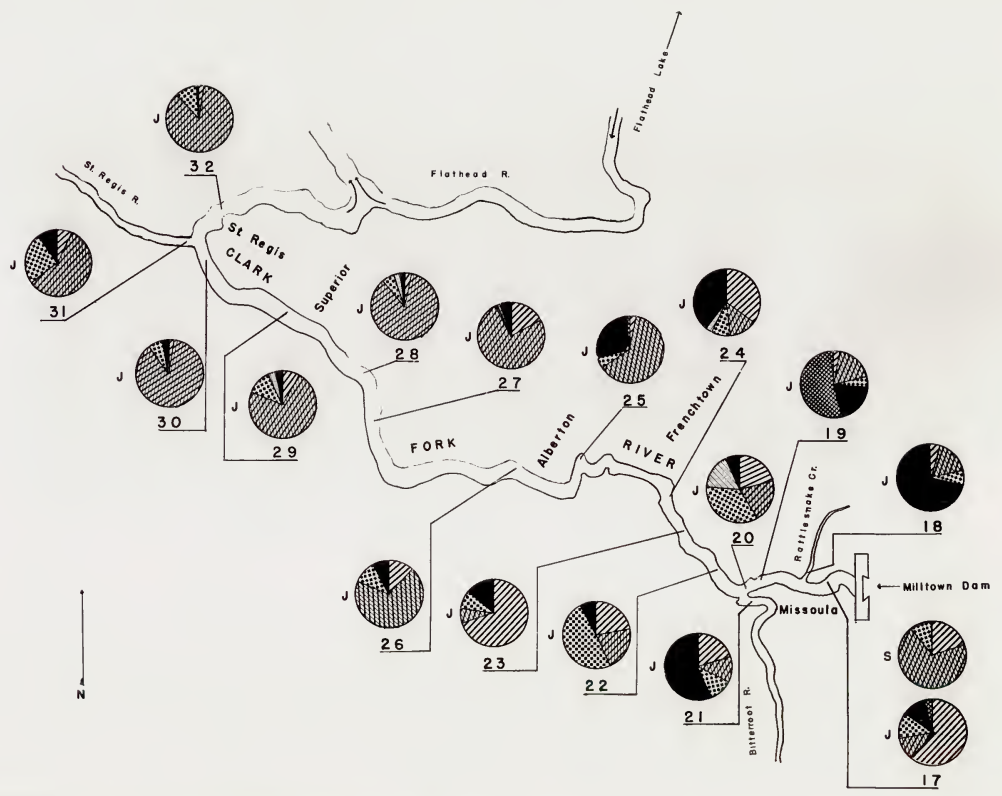




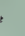


